\title{
Effectivity of Interactive Multimedia and Student Activity Sheets with Writing-To-Learn (WTL) Strategy in Science Learning for Hearing Impairment Students
}

\author{
Sukarmin*, Sri Poedjiastoeti, Dian Novita, Achmad Lutfi \\ Chemistry Department, Faculty of Matematics and Science \\ Universitas Negeri Surabaya \\ Surabaya, Indonesia \\ sukarmin@unesa.ac.id
}

\begin{abstract}
This study aims to describe the implementation of interactive multimedia and student activity sheets with writing-to-learn (WTL) strategy for hearing impairment students in chemistry subjects in the household. Multimedia interactive were implemented to 9 students Jember Senior High School State for Disabilities and 8 students Bhayangkari Gresik Senior High School for Disabilities with one group pretest - post-test design. The research instruments that used in this study were the observation sheets of interactive multimedia and student activity sheets implementation and pre-test - post-test sheets. Data collection techniques that used in this study were observation and tests, both were analysed descriptively. The WTL strategy components that trained in this study were guided free writing, creative piece, and the end of class reflection. The results of the study showed that (1) the implementation of learning using interactive multimedia and student activity sheets was categorized as good and very good, and (2) it could improve learning outcomes, with $\mathbf{N}$-gain scores categorized from low and high category.
\end{abstract}

Keywords - Interactive multimedia, student activity sheets, Writing-to-learn strategy, hearing impairment student

\section{INTRODUCTION}

Education is basic rights for every human being; including rich, poor, old and children, and those with special needs. Every individual with disabilities have the right to get excellent education in every education units for all types, paths and levels of education in an inclusive and specific condition [1]. Students with disabilities at the secondary education level should be equipped with various subject competencies, especially in science subject. This subject can be developing knowledge based on observation and experiment, if the presentation of this subject is adjusted to the essence of science and specific treatment for disabilities students. Learning through science, not only learning science, will gain an understanding of natural phenomenon; the things that needed for lifelong learning in facing of life challenges. Better science learning is expected to build student that have high intelligent, good characters, and skilled at solving problems. Chemistry in science subject is highly necessary, because there are chemistry around us in everyday life. All material that exists in everyday life is composed and constructed from chemical elements. One way to effective deliver chemistry subject is by using interactive multimedia and student activity sheets.

Interactive multimedia is the usage of various types of media, including texts sounds, graphics, animations, and videos, plus interactive aspects [2]. The use of computers is very helpful for hearing impairment students. For hearing impairment students, computer hardware and software can make artificial sounds can be used as a communication tools for students' discussions. In addition, the computer can be used to access bulletins and electronic media, e-mails, or network services. Student activity sheets can be used as a teacher to help hearing impairment students learn to express their opinions through writing. Student activity sheets contain concepts and instructions of tasks that must be done by students [3]. Science learning equipment for chemistry subjects, which are suitable with the hearing impairment students, should facilitate the delivery of concepts in chemistry subjects. Hearing impairment students have the inability of hearing in different levels and requires optimization of other senses, such as visualization in the form of texts, images, animations, video shows and total communication in hands-on and minds-on activities. The writing-to-learn (WTL) strategy helps students in learning. There are some activities in WTL strategy such as writing, reading, class discussion, teacher presentation, using learning media such as video, and experiment [4].The WTL strategy is the good strategy to be used in learning process, because it can be used at the beginning, during, or the end of learning in the classroom or activities at laboratory.

The WTL strategy is applied through writing activities; students will learn about concepts and also improving ability students in the classroom.WTL strategy consists of three processes which are: (1) Guided free writing, the teacher guides students to write comments in a science activity with more specific goals, (2) Creative piece, students are asked to describe a situation, thing, or living thing and write down what things they notice and then the teacher discusses with students about that, (3) The end of class reflection, at the end of learning process, the teacher engaging the students to think and write down some important things the students get in the learning process[4]. 
Based on the these descriptions, it is necessary to conduct research to determine the effectiveness of the implementation of interactive multimedia and student activity sheets with the WTL strategy on chemistry in daily life topic in two schools of hearing impairment. The schools for this research are Jember Senior High School State for Disabilities and Bayangkari Gresik Senior High School for Disabilities.

\section{METHODS}

This research was conducted with one group pretestposttest research design. The research instrument that used in the trial was the implementation observation sheet and the student ability test sheets in the form of pre-test and posttest and would be analyzed descriptively.

\begin{tabular}{|ccc|}
\hline Pre-test & treatment & Post-test \\
$\mathrm{O} 1$ & $\mathrm{X}$ & $\mathrm{O} 2$ \\
\hline
\end{tabular}

Keterangan :

O1: pre-testscore or student's learning outcome before implementation of interactive multimedia and student activity sheets with WTL strategy

$\mathrm{X}$ : treatment or implementation ofinteractive multimedia and student activity sheets with WTL strategy

O2: post-test score or student's learning outcome after implementation of interactive multimedia and student activity sheets with WTL strategy

Analysis of implementation of writing-to-learn (WTL) strategy is using three components: (1) guided free writing, (2) creative piece, and (3) end-off-class reflection. The analysis of WTL strategy implementation is described by associating the implementation of the interactive multimedia and student activity sheets because both of them contain the WTL components. WTL strategy analysis is described as good if the implementation of the interactive multimedia and student activity sheets described as good. The data results that obtained from two schools (Jember and Gresik) can be used as a comparison fundamental for analysis. Interpretation criteria scores from the implementation are present in Table 1.

TABLE I. PERSENTATION CATEGORY OF IMPLEMENTATION INTERACTIVE MULTIMEDIA AND STUDENT WORKSHEET

\begin{tabular}{|c|c|}
\hline Percentage (\%) & Category \\
\hline $0-20$ & Very Less \\
\hline $21-40$ & Less \\
\hline $41-60$ & Enough \\
\hline $61-80$ & Good \\
\hline $81-100$ & Very Good \\
\hline
\end{tabular}

Pre-test and post-test score is analysed by this formula:

\section{$\mathrm{N}-\mathrm{Gain}=\frac{s_{\text {post } \mathrm{t}-s_{p r r}}}{s_{\max }-s_{p r}}$}

Explanation:

S post : post-test score

S pre : pre-test score

$\mathrm{S}$ max :ideal maximum score

Student's individual learning outcomes is stated as having improvement in high, average or low category according to the n-gain score that is fit with the criteria as in table 1 .

TABLE II. N-GAIN CRITERIA
\begin{tabular}{|c|c|}
\hline Normalized Gain & Category \\
\hline $\mathrm{g}<0.30$ & Low \\
\hline $0.31<0.70$ & Medium \\
\hline $\mathrm{g}>0.71$ & High \\
\hline \multicolumn{2}{|c|}{ Adaptation [ 7] }
\end{tabular}

\section{RESULT AND DISCUSSION}

This research was to know the effectiveness of interactive multimedia and student activity sheets with WTL strategy on chemistry subject. This research was carried out at Jember Senior High School State for Disabilities and Bayangkari Gresik Senior High School for Disabilities, especially hearing impairment student. Interactive multimedia implementation could be seen from the stages that carried out during the learning process, from the students navigated the multimedia stage until they did the interactive stage. Implementation of student activity sheets could be seen by observing some aspects such as reading the title, reading the learning objectives, knowing tools, materials and procedures of experiment, giving the ideas and drawing pictures, matching the suitable things/products, and reflecting all activities including finished activities, partially finished activities and unfinished activities. Each of WTL strategy components was contained in learning activities. Guided free writing component was contained in knowing tools, materials and procedures of experiment activity. Creative piece component was contained in giving the ideas and drawing pictures and matching the suitable things/products activity. The end of class reflection component was contained in reflecting activity.

Based on the data in Table III about the implementation of multimedia in Jember Senior High School State for Disabilities and Bayangkari Gresik Senior High School for Disabilities, the percentage on the navigation aspect was $100 \%$. The navigation aspect was really implemented perfectly because in both schools there were no obstacles when navigating. Every student can easily try this aspect. This is in accordance with the opinion of Arsyad (2002) visual-based media (images) in this case play an important role in the learning process, because visual media can facilitate understanding and strengthen memory[8]. The next aspect is the concept that is divided into three things, the results of the implementation are $100 \%$ in Jember Senior High School State for Disabilities and Bayangkari Gresik Senior High School for Disabilities. The difference lies in component (b) in the concept aspect that is $100 \%$ 
implemented in Jember Senior High School State for Disabilities and $88 \%$ in Bayangkari Gresik Senior High School for Disabilities.

TABLE III. IMPLEMENTATION OF INTERACTIVE MULTIMEDIA

\begin{tabular}{|c|c|c|c|}
\hline \multirow[b]{2}{*}{ No. } & \multirow[b]{2}{*}{$\begin{array}{c}\text { Interactive } \\
\text { Multimedia Aspect }\end{array}$} & \multicolumn{2}{|c|}{ Implementation percentage $(\%)$} \\
\hline & & $\begin{array}{l}\text { Jember Senior } \\
\text { High School State } \\
\text { for Disabilities }\end{array}$ & $\begin{array}{c}\text { Gresik Senior } \\
\text { High School } \\
\text { State for } \\
\text { Disabilities }\end{array}$ \\
\hline 1. & Navigation & 100 & 100 \\
\hline \multirow{4}{*}{2.} & Concept(s) & & \\
\hline & a. Chart(s) & 100 & 100 \\
\hline & b. Concept(s) & 100 & 88 \\
\hline & c. Example(s) & 100 & 100 \\
\hline \multirow{4}{*}{3.} & WTL Strategy & & \\
\hline & $\begin{array}{c}\text { a. Guided Free } \\
\text { Writing }\end{array}$ & 100 & 100 \\
\hline & b. Creative Piece & 75 & 88 \\
\hline & $\begin{array}{c}\text { c. The End of Class } \\
\text { Reflection }\end{array}$ & 78 & 91 \\
\hline 4. & Analysis & 81 & 94 \\
\hline 5. & Video & 100 & 100 \\
\hline \multirow[t]{4}{*}{6.} & Interactive & & \\
\hline & a. Writing & 92 & 100 \\
\hline & $\begin{array}{l}\text { b. Matching suitable } \\
\text { products }\end{array}$ & 75 & 84 \\
\hline & $\begin{array}{l}\text { c. Answering the } \\
\text { questions }\end{array}$ & 78 & 100 \\
\hline
\end{tabular}

The most important aspect of implementing interactive multimedia is the implementation of the WTL strategy. The components of the WTL strategy are Guided Free Writing, Creative Piece, and The End of Class Reflection. The results of the implementation of the interactive multimedia on aspects of the WTL strategy have differences between the results in Jember Senior High School State for Disabilities and Bayangkari Gresik Senior High School for Disabilities. The WTL component that gets the same results in both schools is Guided Free Writing of $100 \%$. A very unique thing is the difference between the results of the creative piece and the end of class reflection in both schools. It can be seen in table III that the implementation of creative piece and the end of class components in Jember Senior High School State for Disabilities is $75 \%$ and $78 \%$ respectively. Meanwhile the same component in Bayangkari Gresik Senior High School for Disabilities is $88 \%$ and $91 \%$. The difference in the percentage of implementation of the WTL component in both schools is unique because one of the differences found in the school is quite far. There is also a unique factor that makes the difference between the implementation of the WTL component in both schools clearly visible about the condition of the hearing impairment students themselves. The fact is that the condition of hearing impairment students at the Guided free writing stage has no significant problems because the component only focuses on how the teacher guides students to write. The location of the creative piece and the end of class uniqueness is the focus that occurs when the implementation is also influenced by the ability of students to accept an understanding of creative thinking and to conclude the results of learning so that the results of the two components are always unique. Arum (2010) argues that the level of ignorance can affect the intelligence of hearing impairment students so that the results of interactive multimedia implementation in Gresik are better than in Jember because of differences in student intelligence[9]. The following aspects are very successful videos performed at $100 \%$ in both schools while in the analytical and interactive aspects there is a difference in results and varies in both schools. Variations in the results of the implementation of the two schools certainly have the same reasons as the aspects of the two components of the WTL strategy, which are dependent on the intelligence of hearing impairment students. The thing that happened related to this aspect was the intelligence of hearing impairment students in Gresik was higher than the students at Jember.

TABLE IV. IMPLEMENTATION OF STUDENT ACTIVITY SHEETS

\begin{tabular}{|c|c|c|c|}
\hline \multirow[b]{2}{*}{ No. } & \multirow{2}{*}{$\begin{array}{c}\text { Interactive } \\
\text { multimedia aspect }\end{array}$} & \multicolumn{2}{|c|}{ Implementation percentage ( $\%)$} \\
\hline & & $\begin{array}{l}\text { Jember Senior High } \\
\text { School State for } \\
\text { Disabilities }\end{array}$ & $\begin{array}{c}\text { Gresik Senior } \\
\text { High School State } \\
\text { for Disabilities }\end{array}$ \\
\hline 1. & Chemistry info & 100 & 100 \\
\hline \multirow{4}{*}{2.} & \multicolumn{2}{|l|}{ Concept map } & \\
\hline & a. Title & 100 & 100 \\
\hline & b. Objective & 94 & 94 \\
\hline & c. Description & 100 & 100 \\
\hline \multirow{4}{*}{3.} & \multicolumn{2}{|l|}{ Guided Free Writing } & \\
\hline & $\begin{array}{lrl}\text { a. Tools } & \text { and } \\
\text { Materials } & \\
\end{array}$ & 100 & 100 \\
\hline & b. Procedure & 92 & 100 \\
\hline & c. Observations & 97 & 100 \\
\hline 4. & Analysis & 78 & 100 \\
\hline 5. & Conclusions & 100 & 100 \\
\hline \multirow[t]{4}{*}{6.} & \multicolumn{2}{|l|}{ Creative Piece } & \\
\hline & a. Let's be creative! & 78 & 81 \\
\hline & $\begin{array}{l}\text { The End of Class } \\
\text { Reflection }\end{array}$ & & \\
\hline & a. Let's recall it! & 72 & 84 \\
\hline
\end{tabular}

Based on table IV about the implementation of student worksheets in Jember Senior High School State for Disabilities a perfect percentage of $100 \%$ was obtained in some aspects and some of its components. These aspects and components include chemical information, title components, descriptions, components of equipment and materials, and conclusions. The same results are also obtained from table VI, namely the implementation of student worksheets in Bayangkari Gresik which is $100 \%$ perfect in some aspects and components. All aspects that are $100 \%$ in Jember Senior High School State for Disabilities are also owned by Bayangkari Gresik and especially in aspects of guided free writing, all components have $100 \%$ compliance. This proves that the implementation of student worksheets in the form of Gresik is better than the implementation at the Jember Senior High School State for Disabilities. One strong reason is the same as when discussing the implementation of interactive multimedia, namely the difference in intelligence of hearing impairment students. Emotional factors of hearing impairment students are also one of the causes of the better implementation of student worksheets in Gresik than in Jember. Sudiraharti (2008) said that emotional disturbances experienced by hearing impairment children are caused by their difficulties in expressing their thoughts and desires 
orally[10]. Hastuti (2011) also states that hearing loss causes negative effects on hearing impairment children, including egocentrism, more than normal children and easily offended by others[11]. Based on this, it can be revealed that the emotional condition of hearing impairment students at Bayangkari Gresik Middle School is more controlled than in Jember Senior High School State for Disabilities. It can be seen in Figure 1 that the student worksheets in Jember Senior High School State for Disabilities although it is complete, there are still some answer errors in the work step and observation components. Figure 2 shows that the implementation of student worksheets in the guided free writing component in Bayangkari Gresik is better than in Jember. It can be seen in figure 2 that the student worksheets in Bayangkari Gresik are complete and correct in the procedure and observation components.
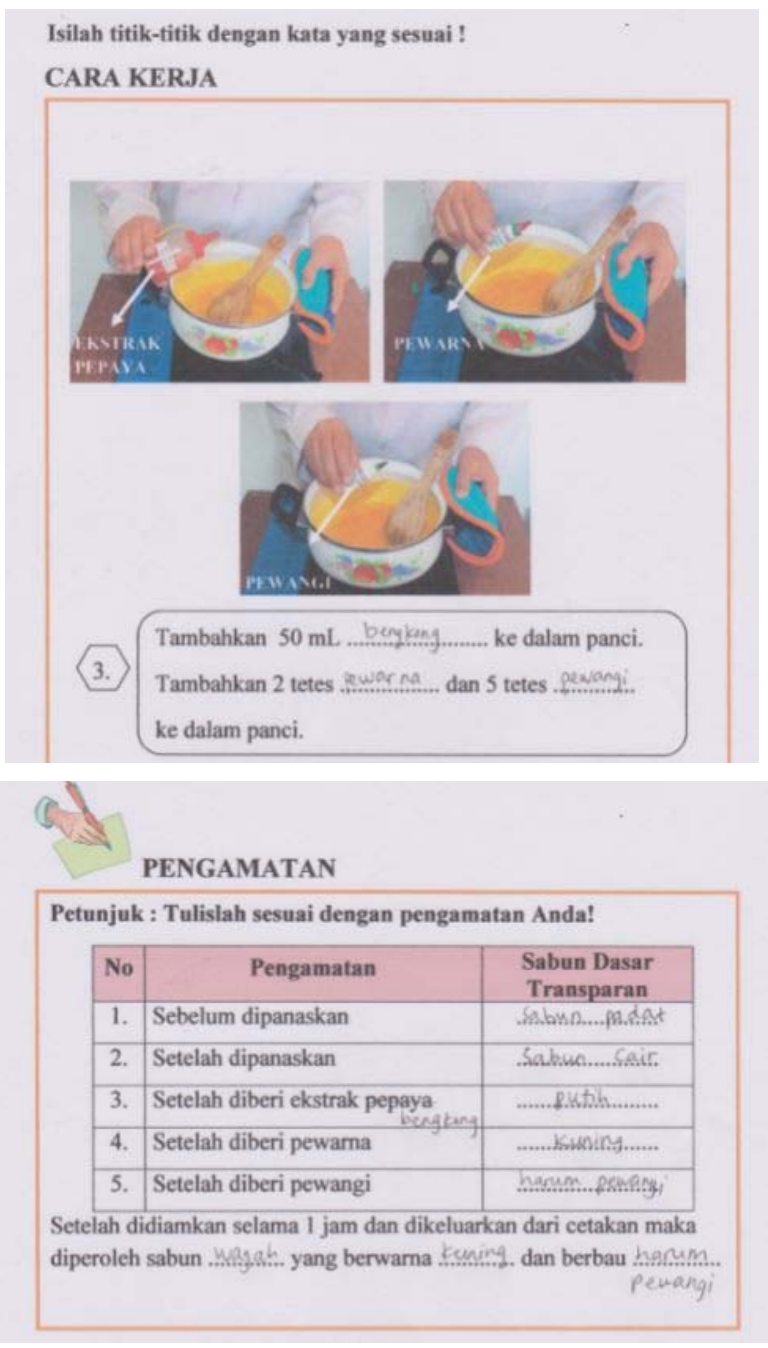

Fig. 1. Answer of student activity sheet guided free writing on component procedure and observation in Jember Senior High School State for Disabilities
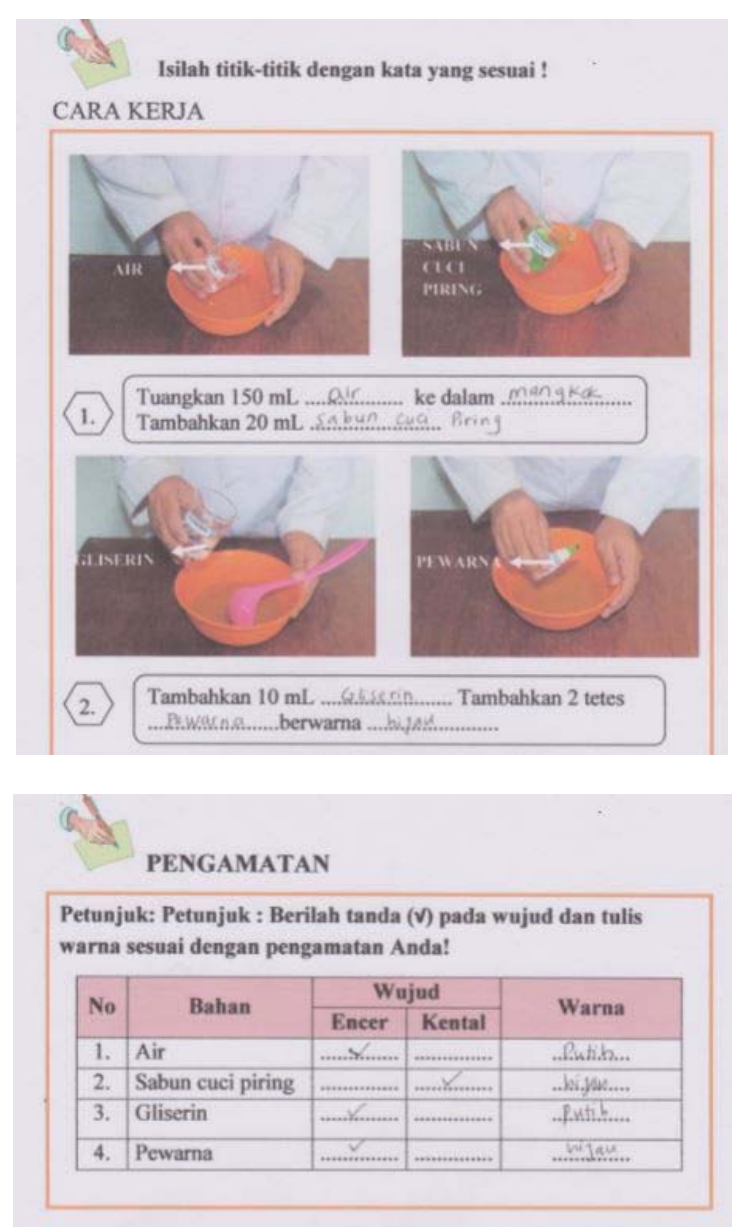

Fig. 2. Answer of Student activity sheet guided free writing on component procedure and observation in Bayangkari Gresik

The next result that deserves to be reviewed is the difference in the percentage of implementation in the analysis aspect which reveals that hearing impairment students in Bayangkari Gresik are more optimal than in Jember. This is due to differences in the conditions of students' intelligence in their role to perform the analysis aspects in the student worksheets as expressed by Arum [9]. The obvious difference is also found in the creative piece aspect and the end of class reflection aspect both two schools. Hearing impairment students understand information through the senses of sight assisted with other senses that are still functioning properly, then recorded in the brain through visual perception [9]. Based on argues, hearing impairment proved to be less than optimal in completing student worksheets in the creative piece and the end of class reflection aspects. Hearing impairment students really have difficulty in completing student activity sheets on the creative piece and the end of class reflection aspects so that the implementation is not perfect even though it is still classified as good. Figures 3 and 4 help to reveal the results of the students' answers in completing the student worksheets in the creative piece aspect. Figures 5 and 6 can be used as evidence to reveal that the worksheets of students on the end of class aspect in Bayangkari Gresik are better than in Jember Senior High School State for Disabilities. 


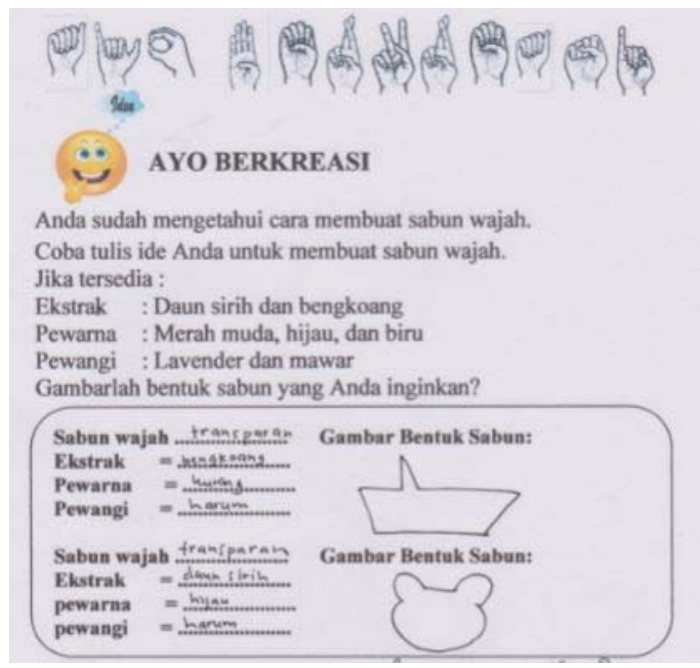

Fig. 3. Answer of Student activity sheet creative piece aspect in Jember Senior High School State for Disabilities

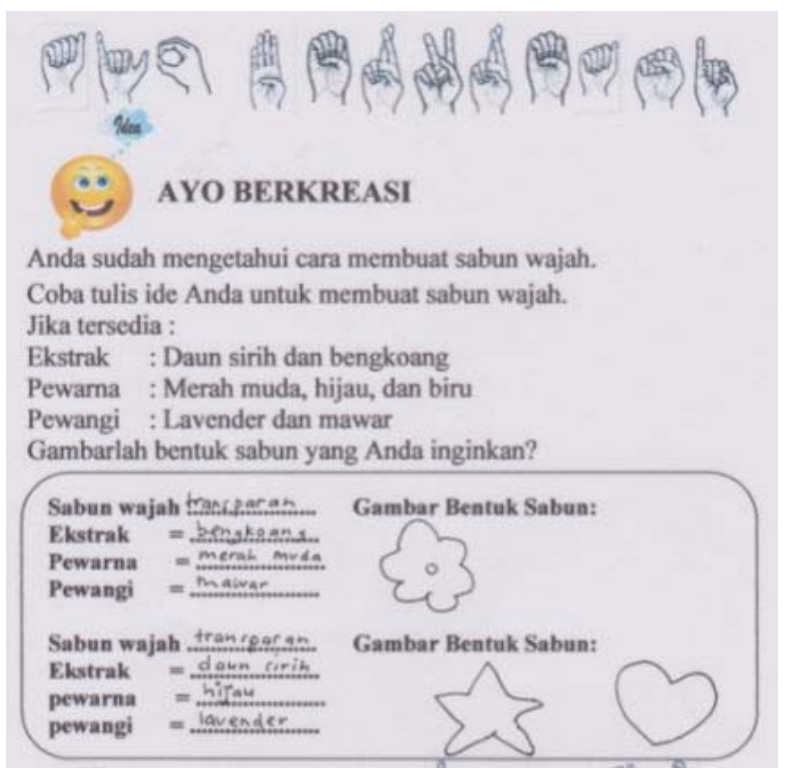

Fig. 4. Answer of Student activity sheet creative piece aspect in Bayangkari Gresik

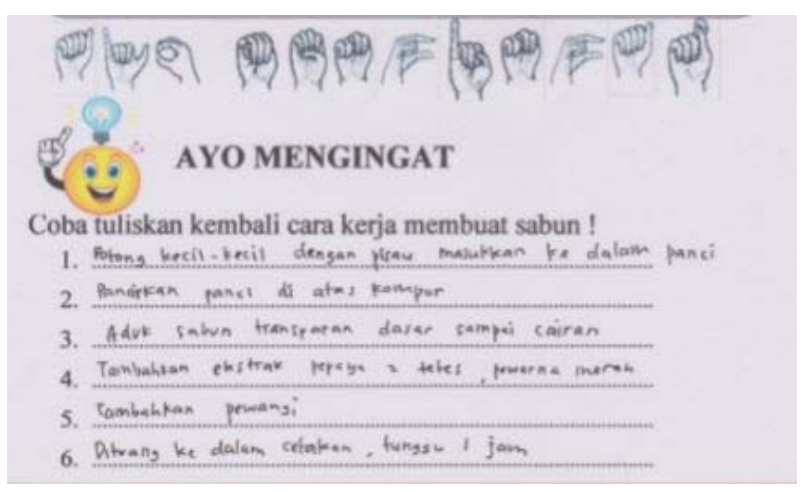

Fig. 5. Answer of Student activity sheet the end of class reflection aspect in Jember Senior High School State for Disabilities

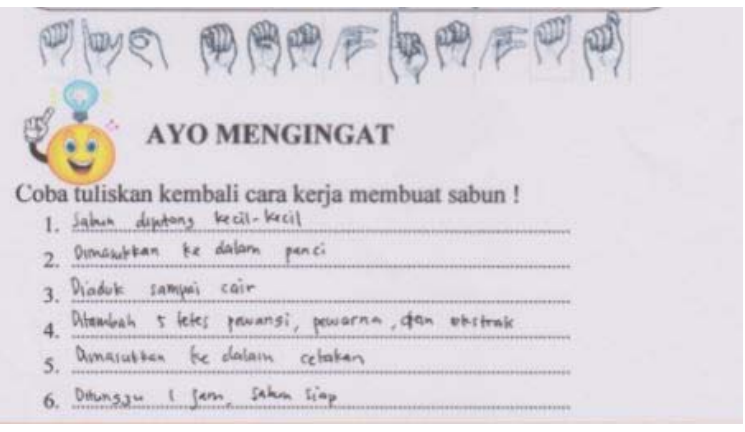

Fig. 6. Answer of Student activity sheet the end of class reflection aspect in Bayangkari Gresik

TABLE V. PRE-TEST AND POST-TEST SCORE OF JEMBER STUDENTS

\begin{tabular}{|c|c|c|c|c|c|}
\hline No & Name & Pre-test Score & $\begin{array}{c}\text { Post-test } \\
\text { Score }\end{array}$ & N-Gain & Category \\
\hline 1 & $\mathrm{H}$ & 10.53 & 21.05 & 0.12 & Low \\
\hline 2 & $\mathrm{AS}$ & 15.79 & 31.58 & 0.19 & Low \\
\hline 3 & $\mathrm{JM}$ & 15.79 & 31.58 & 0.19 & Low \\
\hline 4 & $\mathrm{M}$ & 10.53 & 10.53 & 0.00 & Low \\
\hline 5 & $\mathrm{~B}$ & 5.26 & 10.53 & 0.06 & Low \\
\hline 6 & $\mathrm{WK}$ & 10.53 & 15.79 & 0.06 & Low \\
\hline 7 & $\mathrm{R}$ & 5.26 & 15.79 & 0.11 & Low \\
\hline 8 & $\mathrm{JZ}$ & 5.26 & 21.05 & 0.17 & Low \\
\hline 9 & $\mathrm{~K}$ & 15.79 & 31.58 & 0.19 & Low \\
\hline
\end{tabular}

TABLE VI. PRE-TEST AND POST-TEST SCORE OF BHAYANGKARI GRESIK STUDENTS

\begin{tabular}{|c|c|c|c|c|c|}
\hline No & Name & Pre-test Score & $\begin{array}{c}\text { Post- } \\
\text { test } \\
\text { Score }\end{array}$ & N-Gain & Category \\
\hline 1 & I & 15.79 & 31.58 & 0.19 & Low \\
\hline 2 & A & 21.05 & 42.11 & 0.27 & Low \\
\hline 3 & AA & 42.11 & 89.47 & 0.82 & High \\
\hline 4 & AF & 21.05 & 84.21 & 0.80 & High \\
\hline 5 & EK & 15.79 & 84.21 & 0.81 & High \\
\hline 6 & AA & 10.53 & 84.21 & 0.82 & High \\
\hline 7 & FP & 10.53 & 42.11 & 0.35 & High \\
\hline 8 & SW & 5.26 & 26.32 & 0.22 & High \\
\hline
\end{tabular}

Based on the results of the pre-test and post-test in table $\mathrm{V}$, the magnitude of the $\mathrm{N}$-gain as a whole is in the low category. This indicates that the understanding of 9 hearing impairment students in Jember Senior High School State for Disabilities is not optimal. This can occur due to several factors, one of which is the low ability of students to understand the chemical representation delivered in learning. Chemical representation can be explained by three levels of representation in chemical concepts, namely the macroscopic, submicroscopic, and symbolic levels (Chitleborough, 2004) [10]. This has revealed that there are several levels that have not been fully understood by hearing impairment students. The thing that supports the cause of the 
low increase in pre-test and post-test is that it is not optimal to implement the interactive multimedia and student worksheets even though it is still in the good category. More attention is needed from teachers who teach with total communication methods so that hearing impairment students can break through their limitations. Laesi (2013), the Komtal method can be done more dominantly not because this method is better than other methods, but because the Komtal method can make it easier for individuals with hearing loss to improve their communication skills, so that individuals with hearing loss do not find it difficult to carry out their roles, can run communication activities with other people [11]. Poedjiastoeti (2010), total communication is one of the basic communication methods for hearing impairment children who combine oral methods, cues, and finger spelling. Based on the explanation of several experts about increasing the activity of the total communication method related to the WTL strategy, it will streng then the effectiveness of the WTL strategy, especially in Jember Senior High School State for Disabilities [12]. Based on the results of the pre-test and post-test in table VI it is known that the overall N-gain is in the low and high categories. This indicates that almost all of the understanding of 8 hearing impairment students in Bayangkari Gresik is better than students' understanding at Jember Senior High School State for Disabilities. This is evidenced by the large percentage of implementation of interactive multimedia and student activity sheets at Bayangkari Gresik Public High Schools in Tables III and IV rather than the magnitude of the implementation of interactive multimedia and student activity sheets in Jember Senior High School State for Disabilities in Tables III and IV. Figures 1 through Figure 6 have also illustrated the evidence of student worksheets with WTL strategies. more optimal at Bayangkari Gresik High School than Jember Senior High School State for Disabilities. This if it is associated with the results of the pretest and post-test shows the alignment of abilities possessed by hearing impairment students in each school. The results of the pre-test and post-test found in both schools experienced an increase with the implementation of the WTL strategy.

Strategic Writing to learn is a strategy that is expected to help hearing impairment students in optimal learning. Yusefni (2015) said that various Writing to learn activities are reading, class discussions, teacher presentations, media such as videos, and practicum can be said to have been done well [13]. The expected WTL strategy based on the analysis of existing data related to the effectiveness of interactive multimedia and student worksheets on both schools is included in both the Jember Senior High School State for Disabilities and excellent at Bayangkari Gresik. The effectiveness of interactive multimedia in both schools can prove the statement related to the function of learning media by Arsyad (2002), with was improving the effectiveness and efficiency of learning, increasing student learning passion, increasing learning interest and motivation, making students interact directly with reality, activating the communication process in learning, and improve the quality of learning [8]. Nilson (2003), explains the purpose of writing to learn, among others, to make students think actively about the material being studied, help teachers see students 'understanding of the material, improve students' writing skills, and help in optimizing student learning [14]. All of Nelson's general statements have been reached on the implementation of the WTL strategy at the Jember Senior
High School State for Disabilities and Bayangkari Gresik. Daryanto (2011) added that education is a process of maturing students so that they can develop their talents, potential, and skills for their lives [15]. Daryanto's statement is in line with the effectiveness of interactive multimedia and student worksheets with WTL strategies that can develop the talents, potential, and skills possessed for life better.

\section{CONCLUSIONS}

Based on the analysis, it can be concluded that the effectiveness of interactive multimedia and student activity sheets with the WTL strategy is categorized as good and very good. The results are shown from the percentage of interactive multimedia and student activity sheets implementation at Jember Senior High School State for Disabilities and Bhayangkari Gresik senior high school for disabilities which are shows good and very good score achievement. Meanwhile, the effectiveness of interactive multimedia and student activity sheets is also supported by the results of the pre-test and post-test which are improved in each of school. Students in Jember Senior High School State for Disabilities obtained n-gain in the low category. Meanwhile Students in Bayangkari Gresik Senior High School for Disabilities have better improvements than schools in Jember. Students in Bayangkari Gresik Senior High School for Disabilities obtained n-gain in the low and high category.

\section{ACKNOWLEDGMENT}

The author is very grateful to the Dean as the head of the Faculty of Mathematics and Natural Sciences which has facilitated the completion of this manuscrip. The authors are also grateful to Luky Biyam Susanti who has helped set the space and prepare the completeness of the data

\section{REFERENCES}

[1] DPR RI. Salinan Undang-Undang Republik Indonesia Nomor 8 Tahun 2016 tentang Penyandang Disabilitas. Jakarta.2016

[2] Depdiknas. Panduan Pengembangan Bahan Ajar. Jakarta: Balitbang Depdiknas. 2008

[3] Setiawan Agus. Multimedia Interaktif dan e-Learning. Prodi IPA SPS UPI. Bandung: 19-12-2007

[4] Lang, H.G., dan Albertini, J.A. "Construction of Meaning in the Autentic Science Writing of Hearing impairment Student". Journal of Hearing impairment Study and Hearing impairment Education, Vol 6. No. 4 pp. 258-284. 2001

[5] Sugiyono. Metode Penelitian Pendidikan. Bandung: Alfabeta. 2011

[6] Riduwan. Skala Pengukuran Variabel-Variabel Penelitian. Bandung: Alfabeta. 2015

[7] Hake, R. R. Analyzing Change/Gain Scores (Terjemahan). Jakarta: Gramedia. 1998

[8] Arsyad, A. Media Pembelajaran, edisi 1. Jakarta: PT Raja Grafindo Persada. 2002

[9] Arum, P. "Pengaruh kecerdasan Emosional pada Prestasi Siswa Tunarungu dalam Mata Pelajaran Seni Budaya". Journal of Harmonia vol 10. No.01. 2010

[10] Sudiraharti, P. 2008. Modul Artikulasi dan Optimalisasi Fungsi. Pendengaran. Bandung : Jurusan PLB. (Tidak Diterbitkan)

[11] Laesi, A. "Studi Perbandingan antara Komunikasi Total dengan Ejaan Jari dalam Meningkatkan Kemampuan Membaca Teknis bagi Siswa Tunarungu Kelas III /B Di SLB Kartini Batam”. Jurnal Ilmiah Pendidikan Khusus, Vol 1 No.02. 2013. 
[12] S. Poedjiastoeti. "Pembelajaran Kimia untuk Siswa Tunarungu". Prosiding Seminar Nasional Kimia, Hal. A1 - A15, ISBN 978-979028-298-8. 2010.

[13] Yusfeni, W. "Analisis hubungan Aktivitas Writing to Learn dengan Kemampuan Berkomunikasi Lisan Siswa dalam Pembelajaran Science Writing Heuristic". Proceeding of Simposium Nasional Inovasi dan Pembelajaran sains. Bandung. 2015.
[14] Nilson, dkk. Manajemen. Jilid II Edisi bahasa Indonesia. Bandung: PT. Gramedia Indeks Group, 2003.

[15] Daryanto. Media Pembelajaran. Yogyakarta: Gava Media, 2011. 